\title{
Modelling, Simulation and Dynamic Analysis of the Time Delay Model of the Recuperative Heat Exchanger
}

\author{
DRAGUTIN LJ. DEBELJKOVIĆ, University of Belgrade, \\ Faculty of Mechanical Engineering, Belgrade \\ Original scientific paper \\ UDC: 66.045 .1 \\ GORAN V. SIMEUNOVIĆ, University of Belgrade, DOI: 10.5937/tehnika1603407D
}

Faculty of Mechanical Engineering, Innovation Centre, Belgrade

The heat exchangers are frequently used as constructive elements in various plants and their dynamics is very important. Their operation is usually controlled by manipulating inlet fluid temperatures or mass flow rates. On the basis of the accepted and critically clarified assumptions, a linearized mathematical model of the cross-flow heat exchanger has been derived, taking into account the wall dynamics. The model is based on the fundamental law of energy conservation, covers all heat accumulation storages in the process, and leads to the set of partial differential equations (PDE), which solution is not possible in closed form.

In order to overcome this problem the approach based on physical discretization was applied with associated time delay on the positions where it was necessary and unavoidable.

This is quite new approach, which represent the further extension of previous results which did not include significant time delay existing in the working media.

Simulation results, were derived, showing progress in building such a model suitable for further treatment from the position of analysis as well as the needs for control synthesis problem.

Key words: heat exchangers, time delay processes, physical discretization, simulation

\section{INTRODUCTION}

The heat exchangers are designed to achieve certain requirements in the steady state which implies that transient response of heat exchanger must be known to define correct control strategy. The mathematical model of the heat exchanger must be known in order to determine the transient response.

Large number of researchers was working on this problem within last decade such as [1], [8] and [9].

Solving of this problem in the mentioned papers is based on two approaches:

- Numerical solving of PDE which pulls such drawback as convergence problems, stability, stiffness, etc.

- Laplace transformation which is complicated in this case and demands numerical to original time domain.

Author's address: Dragutin Debeljković, University of Belgrade, Faculty of Mechanical Engineering, Belgrade, Kraljice Marije 16

Paper received: 14.03.2016.

Paper accepted: 19.04.2016.
This problems and the similar ones have motivated the researches to invent new approaches for modelling of this processes in order to obtain larger practical use and not to lose their veracity as well.

In this paper two characteristic methods for modelling of heat exchangers have been considered:

- Analytical approach

- The method of physical discretization.

Finally, the step responses of the derived models are presented in graphic form in order to compare this results for the different methods.

Taking into account the existing time delay makes problem significantly difficult. he problem of investigation of time delay systems has been exploited over many years.

Time delay is very often encountered in various technical systems, such as electric, pneumatic and hydraulic networks, chemical processes, long transmission lines, etc.

The existence of pure time lag, regardless if it is present in the control or/and the state, may cause undesirable system transient response, or even instability. Consequently, the problem of stability analysis for this 
class of systems has been one of the main interests for many researchers.

In general, the introduction of time delay factors makes the analysis much more complicated, as well as in the simulation procedure.

\section{ANALYTICAL APPROACH}

In this paper, the recuperative cross-flow heat exchanger is observed, shown in Figure 1, as a process with distributed parameters.

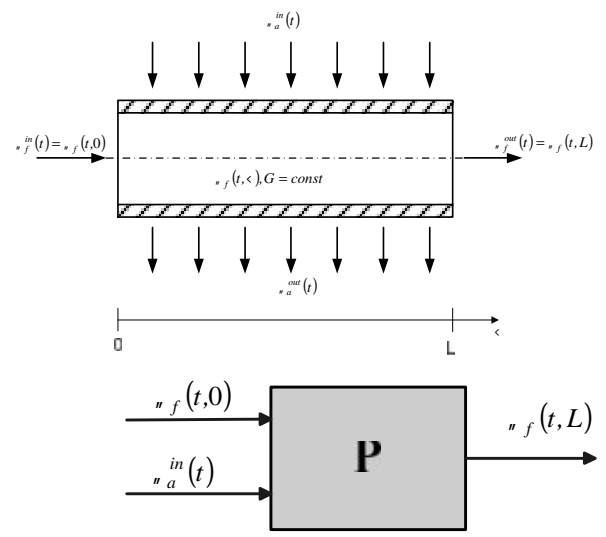

Figure 1 - The symbolic - functional scheme

Among the many kinds of water-to-air heat exchangers, the cross-flow geometry is very common.

The geometry of cross-flow heat exchangers can be complicated, but in this paper we observe the case with the simplest geometry that can be easily computed. This heat exchanger consists of a single tube with fluid (water) flow inside and cross flow of hot air outside.

On the basis of classical assumptions, the mathematical model of the cross- flow heat exchanger after some simple mathematical transformations can be written in the following form.

On the outside of the tube:

$$
G_{a} c_{a}\left(\theta_{a}^{\text {in }}(t)-\theta_{a}^{\text {out }}(t)\right)=2 \alpha_{a w} \pi r_{o} L\left(\theta_{a}(t)-\theta_{w}(t, \xi)\right)
$$

$L$ is the length of the tube, $G_{a}$ is the mass-flow rate of air, $c_{a}$ is the specific heat of air, $\theta_{a}^{\text {in }}$ and $\theta_{a}^{\text {out }}$ are incoming and outgoing air temperatures, $\alpha_{a w}$ is the heat transfer coefficient between the hot air and the tube wall, $r_{o}$ is the outer radius of the tube, $\theta_{a}$ is the air temperature surrounding the tube, and $\theta_{w}$ is the tube wall temperature.

For convenience, the air temperature can be assumed to be approximately:

$$
\theta_{a}(t)=\frac{\theta_{a}^{\text {in }}(t)+\theta_{a}^{\text {out }}(t)}{2}
$$

This can be substituted in Eq. (1).

In the water:

$$
\begin{aligned}
\rho_{f} c_{f} r_{i}^{2} \pi \frac{\partial \theta_{f}(t, \xi)}{\partial t} & =\alpha_{w f} 2 \pi r_{i}\left(\theta_{w}(t, \xi)-\theta_{f}(t, \xi)\right) \\
& -G_{f} c_{f} \frac{\partial \theta_{f}(t, \xi)}{\partial \xi}
\end{aligned}
$$

where $\rho_{f}$ is fluid (water) density, $c_{f}$ is the specific heat of the fluid in the tube, $r_{i}$ is the inner radius, $\theta_{f}$ is the fluid temperature, $\alpha_{w f}$ is the heat transfer coefficient between the wall and fluid, and $G_{f}$ is the mass-flow rate of fluid.

Finally, in the wall of the tube:

$$
\begin{aligned}
\rho_{w} c_{w} \pi\left(r_{o}^{2}-r_{i}^{2}\right) \frac{\partial \theta_{w}(t, \xi)}{\partial t} & =\lambda_{w} \pi\left(r_{o}^{2}-r_{i}^{2}\right) \frac{\partial^{2} \theta_{w}(t, \xi)}{\partial \xi^{2}}+ \\
+ & 2 \pi r_{o} \alpha_{a w}\left(\theta_{a}(t)-\theta_{w}(t, \xi)\right)- \\
& -2 \pi r_{i} \alpha_{w f}\left(\theta_{w}(t, \xi)-\theta_{f}(t, \xi)\right)
\end{aligned}
$$

where $\rho_{w}$ is the wall density, $c_{w}$ is the specific heat of the wall, $\lambda_{w}$ is the wall thermal conductivity.

The boundary and initial conditions are:

$$
\begin{gathered}
\theta_{f}(t, 0)=\theta_{f}^{\text {in }}(t), \quad \theta_{f}(t, L)=\theta_{f}^{\text {out }}(t) \\
\theta_{f}(0, \xi)=0, \quad \theta_{w}(0, \xi)=0
\end{gathered}
$$

Introducing relative deviations in this form:

$$
\begin{aligned}
& \overline{\Delta \theta}_{f}(t, \xi)=\frac{\theta_{f}(t, \xi)-\theta_{f N}(\xi)}{\theta_{f N}\left(\xi_{N}\right)} \\
& \overline{\Delta \theta}_{w}(t, \xi)=\frac{\theta_{w}(t, \xi)-\theta_{w N}(\xi)}{\theta_{w N}\left(\xi_{N}\right)} \\
& \overline{\Delta \theta}_{a}^{i n}(t)=\frac{\theta_{a}^{i n}(t)-\theta_{a N}^{i n}}{\theta_{a N}^{i n}}
\end{aligned}
$$

where $\theta_{f N}, \theta_{w N}, \theta_{a N}^{i n}$ are nominal values.

From Eq. (2), (3), (4), (5) mathematical model of cross-flow heat exchanger is obtained in following form:

$$
\begin{gathered}
\frac{\partial \overline{\Delta \theta}_{f}(t, \xi)}{\partial t}=a_{1} \overline{\Delta \theta}_{w}(t, \xi)-a_{2} \overline{\Delta \theta}_{f}(t, \xi) \\
-a_{3} \frac{\partial \overline{\Delta \theta}_{f}(t, \xi)}{\partial \xi} \\
\frac{\partial \bar{\Delta}_{w}(t, \xi)}{\partial t}=b_{1} \frac{\partial^{2} \overline{\Delta \theta}_{w}(t, \xi)}{\partial \xi^{2}}-b_{2} \overline{\Delta \theta}_{w}(t, \xi) \\
+b_{3} \overline{\Delta \theta}_{f}(t, \xi)+b_{4} \overline{\Delta \theta}_{a}^{i n}(t)
\end{gathered}
$$


where direct expressions for coefficients are given in [11].

\section{PHYSICAL DISCRETIZATION METHOD}

To avoid partial differential equations, the method of physical discretization suggested by [7] is used.

Using this method the observed heat exchanger is divided into the same $p$ cells with the spatial coordinate discretization.

This cells assumes to have homogenous fields of specific physical values.

The qualitative description of the process with distributed parameters can be obtained taking into consideration a big enough number of cells.

The advantage of such an approach is avoiding complex PDE to be set and solved. Balance differential equations are set for an arbitrary cell, taking especially into consideration the first an the last cell which through control boundary have contact with environment.

The flowing index indicates the position of the cell in the heat exchanger. In the physical meaning, the observed cross-flow heat exchanger is divided into the equal $p$ cells with the spatial coordinate discretization.

Assuming that number of cells is big enough, each of this cells can be considered as a process with lumped parameters.

The fundamental low of energy conservation is derived for every cell, so the mathematical model of the cross-flow heat exchanger can be represented as a system of ODE.

Considering $k$-th cell, the balance equation can be written in the following form:

$$
\begin{aligned}
\frac{d \theta_{f, k}(t)}{d t} & =\frac{G_{f}}{\rho_{f} r_{i}^{2} \pi l}\left(\theta_{f, k-1}(t-\tau)-\theta_{f, k+1}(t)\right) \\
& +\frac{2 \alpha_{w f}}{\rho_{f} c_{f} r_{i}}\left(\theta_{w, k}(t)-\theta_{f, k}(t)\right)
\end{aligned}
$$$$
\frac{d \theta_{w, k}(t)}{d t}=\frac{\lambda_{w}}{\rho_{w} c_{w} l}\left(\theta_{w, k-1}(t)-\theta_{w, k}(t)\right)
$$$$
+\frac{2 r_{o} \alpha_{a w}}{\rho_{w} c_{w}\left(r_{o}^{2}-r_{i}^{2}\right)}\left(\theta_{a}(t)-\theta_{w, k}(t)\right)
$$$$
-\frac{2 r_{i} \alpha_{w f}}{\rho_{w} c_{w}\left(r_{o}^{2}-r_{u}^{2}\right)}\left(\theta_{w, k}(t)-\theta_{f, k}(t)\right)
$$$$
\left(\theta_{a}^{\text {in }}(t)-\theta_{a}^{\text {out }}(t)\right)=\frac{2 \alpha_{a w} \pi r_{o} l}{G_{a} c_{a}}\left(\theta_{a}(t)-\theta_{w, k}(t)\right)
$$

where:

$$
\theta_{a}(t)=\frac{\theta_{a}^{\text {in }}(t)+\theta_{a}^{\text {out }}(t)}{2}
$$

and $\tau$ is pure time delay necessary for flow to reach from one cell to the another.

Using Eq. (9-12) the model of cross flow heat exchanger can be obtained in the following form:

$k$-th cell:

$$
\begin{aligned}
\frac{d \theta_{f, k}(t)}{d t} & =-\frac{2 \alpha_{w f}}{\rho_{f} c_{f} r_{i}} \theta_{f, k}(t)+\frac{G_{f}}{\rho_{f} r_{i}^{2} \pi l} \theta_{f, k-1}(t-\tau) \\
& -\frac{G_{f}}{\rho_{f} r_{i}^{2} \pi l} \theta_{f, k+1}(t)+\frac{2 \alpha_{w f}}{\rho_{f} c_{f} r_{i}} \theta_{w, k}(t)
\end{aligned}
$$

$$
\begin{aligned}
\frac{d \theta_{w, k}(t)}{d t} & =\frac{4 \alpha_{a w}^{2} r_{o}^{2} \pi l}{\rho_{w} c_{w}\left(r_{o}^{2}-r_{i}^{2}\right)\left(G_{a} c_{a}+\alpha_{a w} \pi r_{o} l\right)} \theta_{w, k}(t) \\
& -\frac{\lambda_{w}}{\rho_{w} c_{w} l} \theta_{w, k}(t)-\frac{2 r_{o} \alpha_{a w}+2 r_{i} \alpha_{w f}}{\rho_{w} c_{w}\left(r_{o}^{2}-r_{i}^{2}\right)} \theta_{w, k}(t) \\
& +\frac{2 r_{i} \alpha_{w f}}{\rho_{w} c_{w}\left(r_{o}^{2}-r_{i}^{2}\right)} \theta_{f, k}(t)+\frac{\lambda_{w}}{\rho_{w} c_{w} l} \theta_{w, k-1}(t) \\
& +\frac{2 r_{o} \alpha_{a w}\left(G_{a} c_{a}-\alpha_{a w} \pi r_{o} l\right)}{\rho_{w} c_{w}\left(r_{o}^{2}-r_{i}^{2}\right)\left(G_{a} c_{a}+\alpha_{a w} \pi r_{o} l\right)} \theta_{a}^{i n}(t)
\end{aligned}
$$

for the first cell:

$$
\begin{aligned}
\frac{d \theta_{f, 1}(t)}{d t} & =-\frac{2 \alpha_{w f}}{\rho_{f} c_{f} r_{i}} \theta_{f, 1}(t)+\frac{G_{f}}{\rho_{f} r_{i}^{2} \pi l} \theta_{f}^{i n}(t) \\
& -\frac{G_{f}}{\rho_{f} r_{i}^{2} \pi l} \theta_{f, 2}(t)+\frac{2 \alpha_{w f}}{\rho_{f} c_{f} r_{i}} \theta_{w, 1}(t)
\end{aligned}
$$

$$
\begin{aligned}
\frac{d \theta_{w, 1}(t)}{d t} & =\frac{4 \alpha_{a w}^{2} r_{o}^{2} \pi l}{\rho_{w} c_{w}\left(r_{o}^{2}-r_{i}^{2}\right)\left(G_{a} c_{a}+\alpha_{a w} \pi r_{o} l\right)} \theta_{w, 1}(t) \\
& -\frac{\lambda_{w}}{\rho_{w} c_{w} l} \theta_{w, 1}(t)-\frac{2 r_{o} \alpha_{a w}+2 r_{i} \alpha_{w f}}{\rho_{w} c_{w}\left(r_{o}^{2}-r_{i}^{2}\right)} \theta_{w, 1}(t) \\
& +\frac{2 r_{i} \alpha_{w f}}{\rho_{w} c_{w}\left(r_{o}^{2}-r_{i}^{2}\right)} \theta_{f, 1}(t) \\
& +\frac{2 r_{o} \alpha_{a w}\left(G_{a} c_{a}-\alpha_{a w} \pi r_{o} l\right)}{\rho_{w} c_{w}\left(r_{o}^{2}-r_{i}^{2}\right)\left(G_{a} c_{a}+\alpha_{a w} \pi r_{o} l\right)} \theta_{a}^{i n}(t)
\end{aligned}
$$

for the last cell:

$$
\begin{aligned}
\frac{d \theta_{f, p}(t)}{d t} & =-\frac{2 \alpha_{w f}}{\rho_{f} c_{f} r_{u}} \theta_{f, p}(t)+\frac{G_{f}}{\rho_{f} r_{i}^{2} \pi l} \theta_{f, p-1}(t-\tau) \\
& +\frac{2 \alpha_{w f}}{\rho_{f} c_{f} r_{i}} \theta_{w, p}(t)
\end{aligned}
$$




$$
\begin{gathered}
\frac{d \theta_{w, p}(t)}{d t}=\frac{4 \alpha_{a w}^{2} r_{o}^{2} \pi l}{\rho_{w} c_{w}\left(r_{o}^{2}-r_{i}^{2}\right)\left(G_{a} c_{a}+\alpha_{a w} \pi r_{o} l\right)} \theta_{w, p}(t) \\
-\frac{\lambda_{w}}{\rho_{w} c_{w} l} \theta_{w, p}(t)-\frac{2 r_{o} \alpha_{a w}+2 r_{i} \alpha_{w f}}{\rho_{w} c_{w}\left(r_{o}^{2}-r_{i}^{2}\right)} \theta_{w, p}(t) \\
+\frac{2 r_{i} \alpha_{w f}}{\rho_{w} c_{w}\left(r_{o}^{2}-r_{i}^{2}\right)} \theta_{f, p}(t)+\frac{\lambda_{w}}{\rho_{w} c_{w} l} \theta_{w, p-1}(t) \\
+\frac{2 r_{o} \alpha_{a w}\left(G_{a} c_{a}-\alpha_{a w} \pi r_{o} l\right)}{\rho_{w} c_{w}\left(r_{o}^{2}-r_{i}^{2}\right)\left(G_{a} c_{a}+\alpha_{a w} \pi r_{o} l\right)} \theta_{a}^{i n}(t)
\end{gathered}
$$

Introducing relative deviations we define the state, input and output variables in this form:

$$
\begin{aligned}
& \overline{\Delta \theta}_{f, k}(t)=\frac{\theta_{f, k}(t)-\theta_{f N, k}}{\theta_{f N, k}}=x_{k}(t), \\
& \overline{\Delta \theta}_{w, k}(t)=\frac{\theta_{w, k}(t)-\theta_{w N, k}}{\theta_{w N, k}}=x_{k}^{*}(t), \\
& \overline{\Delta \theta}_{f}^{i n}(t)=\frac{\theta_{f}^{i n}(t)-\theta_{f N}^{i n}}{\theta_{f N}^{i n}}=u_{1}(t), \\
& \overline{\Delta \theta}_{a}^{i n}(t)=\frac{\theta_{a}^{i n}(t)-\theta_{a N}^{i n}}{\theta_{a N}^{i n}}=u_{2}(t) .
\end{aligned}
$$

Neglecting the influence of the latter cells to the previous one, what is quite reasonable taking into account the direction of basic steam stream, the mathematical model for $k$-th cell is obtained in the following form:

$$
\begin{aligned}
& \frac{d x_{k}(t)}{d t}=-a_{k 1} x_{k}(t)+a_{k 2} x_{k-1}(t-\tau)+a_{k 4} x_{k}^{*}(t) \\
& \frac{d x_{k}^{*}(t)}{d t}=b_{k 1} x_{k}^{*}(t)+b_{k 2} x_{k-1}^{*}(t-\tau)+b_{k 3} x_{k}(t)+b_{k 4} u_{2}(t)
\end{aligned}
$$

where $k=1,2, \ldots, p$ and expression for general coefficients are given in [4] and theirs particular values in [11].

The mathematical model for the $k$-th cell of the cross-flow heat exchanger is obtained in the state space:

$$
\frac{d \mathbf{x}_{k}(t)}{d t}=A_{k}^{2} \mathbf{x}_{k}(t)+A_{k}^{1} \mathbf{x}_{k-1}(t-\tau)+B_{k} \mathbf{u}(t)
$$

where:

$$
A_{k}^{2}=\left(\begin{array}{cc}
-a_{k 1} & a_{k 4} \\
b_{k 3} & b_{k 1}
\end{array}\right), A_{k}^{1}=\left(\begin{array}{cc}
a_{k 2} & 0 \\
0 & b_{k 2}
\end{array}\right), B_{k}=\left(\begin{array}{cc}
0 & 0 \\
0 & b_{k 4}
\end{array}\right)
$$

$\mathbf{x}_{k}(t)=\left[\begin{array}{ll}x_{k}(t) & x_{k}^{*}(t)\end{array}\right]^{T}, \mathbf{u}(t)=\left[\begin{array}{ll}u_{1}(t) & u_{2}(t)\end{array}\right]^{T}$

For the first cell of the cross-flow heat exchanger the state space equation has the following form:

$\dot{\mathbf{x}}_{1}(t)=A_{1}^{2} \mathbf{x}_{1}(t)+A_{1}^{3} \mathbf{x}_{2}(t)+B_{1} \mathbf{u}(t)$

where:

$A_{1}^{2}=\left(\begin{array}{cc}-a_{11} & a_{14} \\ b_{13} & b_{11}\end{array}\right), \quad A_{1}^{3}=\left(\begin{array}{cc}-a_{13} & 0 \\ 0 & 0\end{array}\right), \quad B_{1}=\left(\begin{array}{cc}a_{12} & 0 \\ 0 & b_{14}\end{array}\right)$

For the last cell the state space equation can be written as follows:

$\dot{\mathbf{x}}_{p}(t)=A_{p}^{1} \mathbf{x}_{p-1}(t-\tau)+A_{p}^{2} \mathbf{x}_{p}(t)+B_{p} \mathbf{u}(t)$

$A_{p}^{1}=\left(\begin{array}{cc}a_{p 2} & 0 \\ 0 & -b_{p 2}\end{array}\right), A_{p}^{2}=\left(\begin{array}{cc}-a_{p 1} & a_{p 4} \\ b_{p 3} & b_{p 1}\end{array}\right), B_{p}=\left(\begin{array}{cc}0 & 0 \\ 0 & b_{p 4}\end{array}\right)$

The state equation and the output of the cross-flow heat exchanger are given with:

$\dot{\mathbf{x}}(t)=A_{0} \mathbf{x}(t)+A_{1} \mathbf{x}(t-\tau) B_{0} \mathbf{u}(t)$
$\mathbf{x}_{i}(t)=\mathbf{c}^{T} \mathbf{x}(t)$

$A_{0}=\left(\begin{array}{ccccccc}A_{1}^{2} & 0 & 0 & 0 & \ldots & 0 & 0 \\ 0 & A_{2}^{2} & A_{2}^{3} & 0 & \ldots & 0 & 0 \\ 0 & 0 & A_{3}^{2} & A_{3}^{3} & \ldots & 0 & 0 \\ \ldots & \ldots & \ldots & \ldots & \ldots & 0 & 0 \\ 0 & 0 & 0 & 0 & \ldots & 0 & A_{p}^{2}\end{array}\right)$,

$A_{1}=\left(\begin{array}{ccccccc}0 & 0 & 0 & 0 & \ldots & 0 & 0 \\ 0 & A_{2}^{2} & A_{2}^{3} & 0 & \ldots & 0 & 0 \\ 0 & 0 & A_{3}^{2} & A_{3}^{3} & \ldots & 0 & 0 \\ \ldots & \ldots & \ldots & \ldots & \ldots & 0 & 0 \\ 0 & 0 & 0 & 0 & \ldots & A_{p}^{1} & A_{p}^{2}\end{array}\right)$

$B=\left(\begin{array}{c}B_{1} \\ B_{2} \\ B_{3} \\ \vdots \\ B_{p}\end{array}\right), \quad \mathbf{x}(t)=\left[\begin{array}{c}\mathbf{x}_{1}(t) \\ \mathbf{x}_{2}(t) \\ \vdots \\ \mathbf{x}_{p}(t)\end{array}\right]$

$\mathbf{c}^{T}=\left[\begin{array}{lllll}0 & 0 & 00 & \cdots & 10\end{array}\right]$

$x_{i}(t)=\theta_{f, p}(t)=x_{p}(t)$

\section{SIMULATION AND COMPARATIVE ANALYSIS}

This section presents the analysis of mathematical model of the cross-flow heat exchanger with respect to different methods considered in the previous sections. 
The nominal characteristic of real cross-flow heat exchanger are given in [11], as well in Appendix A.

The observed heat exchanger is divided into five cells. If the results are unsatisfactory the number of cells must be increased.

\subsection{Results of simulation for the analytical approach}

In the Figure 2 and 3 are shown the step response of the outlet temperature of fluid in the tube for the step change of the inlet fluid temperature and inlet air temperature.

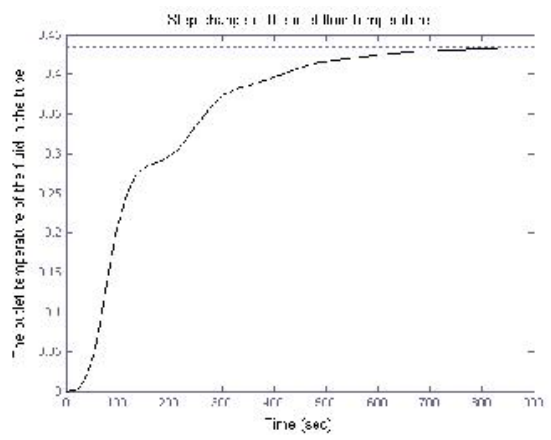

Figure 2 - Step response

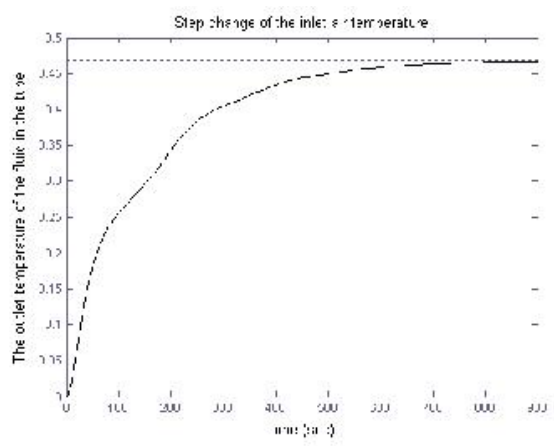

Figure 3 - Step response

\subsection{Results of the simulation for the mathematical} model based on the physical discretization

In the Figure 4, 5, 6 and 7 are shown the step response in the fluid outlet temperature and the temperature profile in the outlet of each cell for the step change in the fluid inlet temperature and the step change in the air inlet temperature.

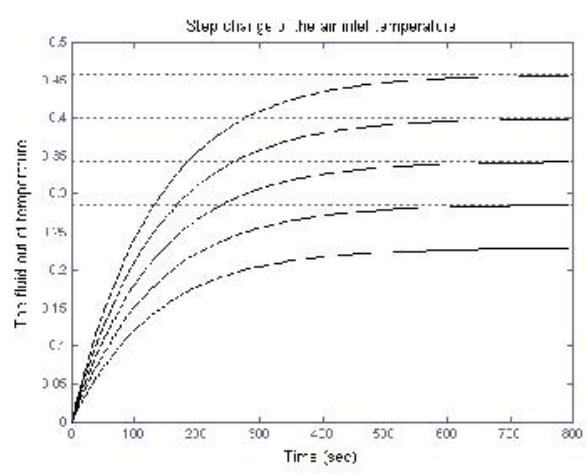

Figure 4-Stet response

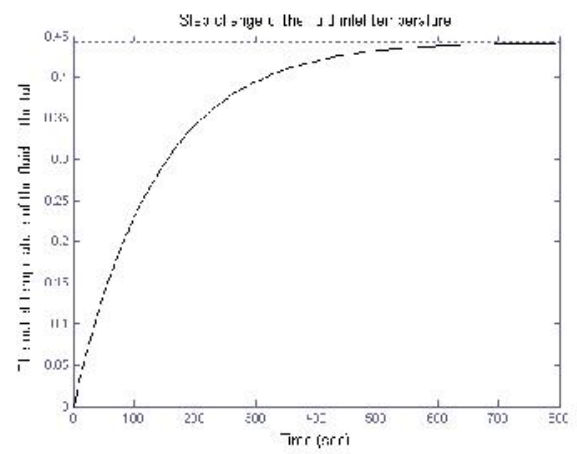

Figure 5-Step response

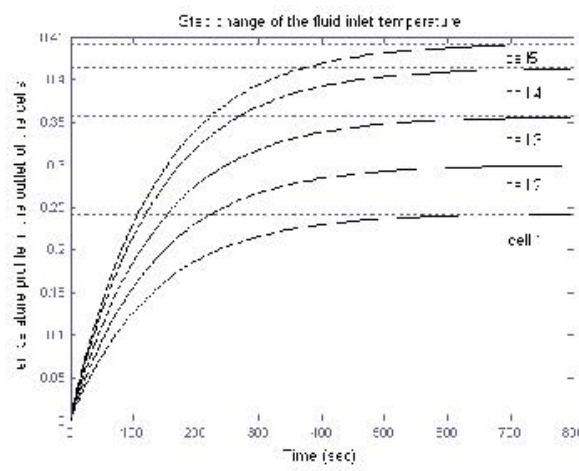

Figure 6 - Step response

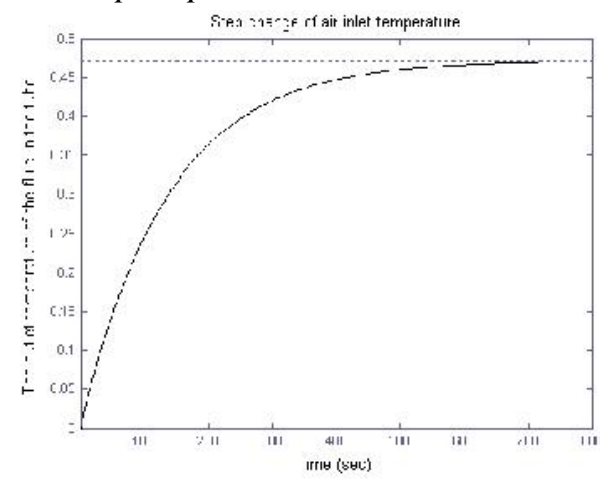

Figure 7 - Step response

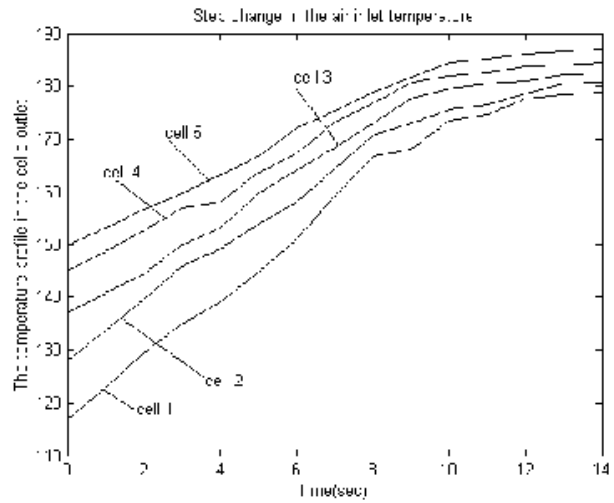

Figure 8-Comparative step response

\subsection{Comparison results of the simulation}

In the Figure 8 and 9 are shown the step response in the fluid outlet temperature and the temperature profile in the outlet of each cell for the step change 
(from $110^{\circ} \mathrm{C}$ to $127^{\circ} \mathrm{C}$ ) in the fluid inlet temperature, using different approaches.

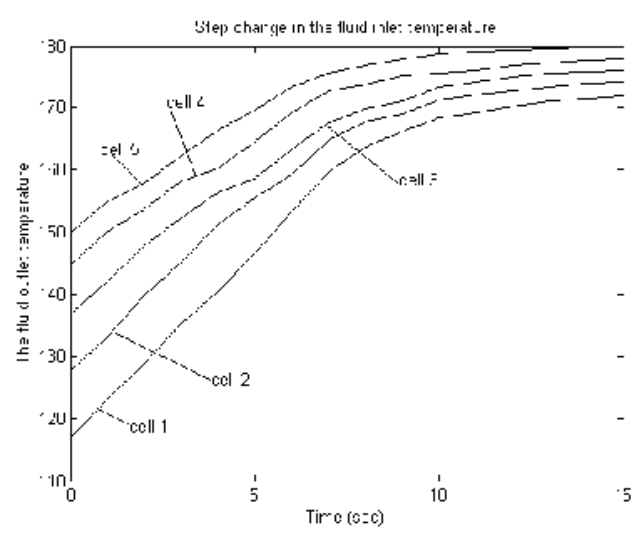

Figure 9 - Comparative step responses

Finally, it should be pointed out that temperatures changes obtained by application of these two methods are quite close, showing high quality of applied modelling.

Incorporated time delay is best shown in the response on Figure 2.

\section{CONCLUSION}

In this paper some characteristic methods of mathematical modelling of the heat exchangers are considered and discussed. Using analytical approach and transport method two mathematical models have been derived, second one including existing time delay in working fluid stream.

This model represent the natural extension of previous models, developed by the same authors, [6], and shows significant improvement of process characteristic personalized in system's model.

APPENDIX A - Nomenclature

Table 1 .

\begin{tabular}{|l|l|l|l|}
\hline & Parameter & Dimension & Value \\
\hline 1. & $c_{w}$ & $\mathrm{~kJ} / \mathrm{kgK}$ & 0,50 \\
\hline 2. & $\rho_{w}$ & $\mathrm{~kg} / \mathrm{m}^{3}$ & $8,12 \cdot 10^{3}$ \\
\hline 3. & $\lambda_{w}$ & $\mathrm{~W} / \mathrm{mK}$ & $0,04 \cdot 10^{3}$ \\
\hline 4. & $r_{o}$ & $\mathrm{~m}$ & 0,015 \\
\hline 5. & $r_{i}$ & $\mathrm{~m}$ & 0,009 \\
\hline 6. & $w_{f}$ & $\mathrm{~m} / \mathrm{s}$ & 0,5 \\
\hline 7. & $G_{f}$ & $\mathrm{~kg} / \mathrm{s}$ & 0,12 \\
\hline 8. & $G_{a}$ & $\mathrm{~kg} / \mathrm{s}$ & 1,8 \\
\hline 9. & $\rho_{f}$ & $\mathrm{~kg} / \mathrm{m}^{3}$ & 952,38 \\
\hline 10. & $c_{f}$ & $\mathrm{~kJ} / \mathrm{kgK}$ & 4,233 \\
\hline
\end{tabular}

\begin{tabular}{|l|l|l|l|}
\hline & Parameter & Dimension & Value \\
\hline 11. & $\alpha_{a w}$ & $W /\left(m^{2} K\right)$ & 220 \\
\hline 12. & $\rho_{a}$ & $k g / m^{3}$ & 0,748 \\
\hline 13 & $\alpha_{w f}$ & $W /\left(m^{2} K\right)$ & 3800 \\
\hline 14. & $c_{a}$ & $k J / k g K$ & 1,097 \\
\hline 15. & $L$ & $m$ & 6 \\
\hline 16. & $\theta_{f N}^{i n}$ & ${ }^{\circ} C$ & 110 \\
\hline 17. & $\theta_{a N}^{i n}$ & ${ }^{\circ} C$ & 200 \\
\hline
\end{tabular}

\section{AKCNOLEDGMENT}

This work has been supported by the Ministary of Science and Technological Department of Serbia under the Project OI 174001.

\section{REFERENCES}

[1] S. Alotaibi, M. Sen, B. Goodwine, K. T. Yang, Controllability of Cross-Flow Heat Exchangers, International Journal of Heat and Mass Transfer, Vol. 47, 913-924, 2004.

[2] D. Debeljković, V. Mulić, G. Simeunović, Heat Exchanger Dynamics - Part I, Cigoja press, Belgrade, 2002.

[3] D. Debeljković, V. Mulić, G. Simeunović, Heat Exchanger Dynamics - Part II, Cigoja press, Belgrade, 2004.

[4] D. Debeljković, G. Simeunović, V. Mulić, Mathematical Model of Objects and Plants in Automatic Control Systems, Planeta print, Belgrade, 2006.

[5] Debeljkovic, D. Lj., D. Z. Stevic, G. V. Simeunović, Comperative analysis of different methods in mathematical modelling of the recuperative heat exchangers, Proc. $19^{\text {th }}$ International Conference on Nuclear Engineering, Tokyo (Japan),, May 16 - 18), Paper No. ICONE 19 - 43124, CD-Rom, 2011.

[6] D. Debeljkovic, D. Stevic, G. Simeunović, Dynamic properties and geometric optimization of double heat exchangers based on controlability condition number, Proc. $19^{\text {th }}$ International Conference on Nuclear Engineering, Tokyo (Japan), May 16 - 18, Paper No. ICONE 19 - 43128, CD-Rom, 2011.

[7] Lj. Grujić, D. Debeljković, Differential Discrete Modelling and Controllability and Observability Analysis of Heat Exchangers, Technika, No 7-8, 1978.

[8] Romie F. E, Transient Response of the Counter-Flow Heat Exchanger, J. Heat Transfer 106 (3), 620-626, 1984. 
[9] Roetzel W, Y. Xuan, Transient/Response of Parallel and Counter-Flow Heat Exchangers, J. Heat Transfer, 114 (2), 510-512, 1992.

[10]Spiga, G, M. Spiga, Two - Dimensional Transient Solution for Cross-Flow Heat Exchangers with Neither
Gas Mixe, Journal of Heat Transfer, Vol. 109, May,281-286, 1987.

[11]Stević Z, D, A Contribution to Comparative Dynamic Analysis and Geometric Optimization of Modern Recuperative Heat Exchangers, Ph. D. Dissertation, Belgrade, 2010.

\section{REZIME}

\section{MODELIRANJE, SIMULACIJA I DINAMIČKA ANALIZA REKUPERATIVNOG RAZMENJIVAČA TOPLOTE KORIŠĆENJE MODELA SA VREMENSKIM KAŠNJENJEM.}

Razmenjivači toplote se često koriste kao konstruktivni elemenati u različitim postrojenjima i njihovu dinamika ima veoma važnu ulogu u radu celog sistema. Njihovim radom se uobičajeno upravlja promenom ulazne temperature fluida ili promenom masenog protoka. Na osnovu usvojenih i kritički sagledanih pretpostavki, izveden je linearizovani matematički model razmenjivača toplote sa unakrsnim strujanjem radnih fluida, uzimajući u obzir i dinamiku zida, koji razdvaja radne medijume.

Ovaj model je zasnovan na primeni osnovnog zakona o očuvanju energije, pokriva sva toplotna akumulatorska skladišta u procesu i dovodi do sistema parcijalnih diferencijalnih jednačina (PDE), čije rešenje nije moguće u zatvorenom obliku.

U cilju prevazilaženja ovog problema iskorišćen je pristup zasnovan na fizičkoj diskretizaciji procesa sa prisutnim čistim vremenskim kašnjenjem na pozicijama gde je to bilo neophodno i neizbežno.

Ovo je sasvim novi pristup, koji predstavlja dalji nastavak prethodnih rezultata koje nisu uključili značajno vremensko kašnjenje koje postoji u osnovnom radnom medijumu.

Izvedeni rezultati simulacije, pokazuju napredak u formiranju verodostojnijih modela, pogodnijih za dalji tretman sa pozicije analize, kao i za potrebe sinteze upravljanju tim procesom.

Ključne reči: razmenjivači toplote, procesi sa vremenskim kašnjenjem, fizička diskretizacija procesa, simulacija 